are hunted down, fair game, to turn on spits and freshen the mouth's appetite for wine, I once for three acts watched a sparrow flutter around an opera house's chandelier while every eye was fixed upon Mimi and no one noticed the bird until he dropped dead on the stage abaft of the soprano.

\title{
With Ripley at the Grave of Albert Parenteau / Richard Hugo
}

He is twice blessed, the old one buried here beneath two names and a plastic bouquet from Choteau. He lived his grief out full. From this hill where Crees bury their dead to give them a view, he can study the meadow, the mountains back of mountains, the Teton canyon winding into stone. I want to say something wrong, say, this afternoon they are together again, he and the wife he killed by mistake in the dark and she forgives him. I don't want to admit it's cold alone in the ground and a cold run from Canada with a dog and two bottles of rye.

Say he counted stones along the bottom of the Teton and the stones counted him one of them.

He scrubbed and scrubbed and never could rid his floor of her stain.

He smashed his radio and the outside world that came from it, and something like a radio hum went on in him the slow rest of his life.

This is the first time I knew his white name.

We won't bring him real flowers this afternoon jammed with the glitter of lupin and harebells. This is the west and depth is horizontal.

We climb for a good view of canyons and we are never higher than others, never a chief like him. 
His grave is modern. His anguish goes backthe first tone from struck rock. You and I, we're civilized. We can't weep when it's needed or counts. If you die first, I'll die slow as Big Bear, my pale days thin with age, night after night, the stars callow as children.

\section{Getty / Richard Hugo}

Today, I remembered Getty, the old man at Price's lake who rented boats and coughed and told me he was gone. Moss caked his lungs and a sky I'd forgotten drifted in his eyes.

The brooks I caught were dazzling and wild. I shouted 'Lord love Getty' at the trees. Nothing came back. The young sheen of willows hung over cedars dark and grumpy with age.

I came back early next spring but Getty prophetically blue, had gone, that winter I stayed home in Seattle and wrote hard to make 'alive' and 'violent' do for the sky.

Some days the fish don't bite. You know that. And we die at wrong times, like friday. Whatever day Getty died, it could not be special or wrong, an old man like him, alone with a lake, no urge to go after trout and no particular feeling when nylon arcs out over the water, hangs that one moment all moments pulse, first kiss, first soft light in the eyes of the girl who seemed nothing last week, and settles soft as a far teal and waits.

Let's see. What happened today: a mild fight in the tenure meeting. We voted nine to one 'no.' 